\title{
The Impact of Product Quality on Perceived Value, Trust and Students' Intention to Purchase Electronic Gadgets
}

\author{
Richard Chinomona \\ Department of Logistics, Vaal University of Technology \\ Private Bag X021, Vanderbij/park 1900, South Africa \\ E-mail: rchinos@hotmail.com \\ Loury Okoumba \\ Vaal University of Technology, South Africa \\ David Pooe \\ Vaal University of Technology, South Africa
}

\section{Doi:10.5901/mjss.2013.v4n14p463}

\begin{abstract}
Increasing attention on the role played by product quality on desirable customer behavioural outcomes has been empirically examined over the past decades. Nevertheless, there are significant issues yet to be addressed and resolved, one of which relates to the influences of the quality of electronic gadgets on students' perceived value, trust and their intention to purchase. In view of this research gap, five posited hypotheses are empirically tested using a sample of 151 in South Africa. The results supports all the posited hypotheses except hypothesis four which although positive as postulated, is insignificant. Managerial implications of the findings are discussed and limitations and future research directions are indicated.
\end{abstract}

Keywords: Strategic purchasing, Information technology, Logistics integration, Business performance, Small and Medium Enterprises (SMEs).

\section{Introduction}

The past decade has witnessed a barrage of studies focusing on customer purchase intention (Lin \& Wang, 2006; Chu \& Lu, 2007; Kim, Chan, \& Gupta, 2007; \& Lu \& Hsiao, 2010; Kumar, Lee \& Kim, 2009 \& Paul, Wu, Yeh \& Hsiao, 2011; Wang, Yeh, \& Liao, 2013). The received wisdom is that purchase intention can be regarded as an indicative lead of the actual future purchase (Kanuk, 2007 \& Paul, Wua, Yeh, \& Hsiao 2011). Thus, purchase intention represents the possibility that consumers will plan or be willing to purchase a certain product or service in the future (Wang, Yeh, \& YiWen Liaob 2013). Further to that, an increase in perceived future customer purchase intention can used by business practitioners as a measuring barometer of the business' future survival and possible profitability prospects (Bao, Bao \& Sheng 2011). Owing to this recognized importance of customer purchase intentions, academicians and business practitioners alike, have been interested in understanding the factors that influence customer purchase intentions (Kumar, Lee \& Kim, 2009 \& Paul, Wu, Yeh \& Hsiao, 2011). Among some of the noted predictors of customer purchase intentions in the marketing literature are customer trust in some brands (Chu \& Lu, 2007; Chen, 2008; Lin \& Wang, 2006; Lu \& Hsiao, 2010; Wang, 2008), customer perceived value of the products to be purchased (Wang, Yeh, \& Yi-Wen Liaob 2013; Lu \& Hsiao, 2010) and their overall perception of the quality of the products they need to purchase (Steenkamp, 1990; Miyazaki, Grewal, Dhruv, Goodstein \& Ronald, 2005; Bao, Bao \& Sheng 2011; Roest \& Rindfleisch 2010; Carrillat, 2009)

While most of the previous studies have examined the antecedents of customer or consumer purchase intentions in general, this study is unique in that it focuses on the purchase intention of electronic gadgets such as laptops from a student perspective. In the information and technologically oriented age we live today, the student community is fast becoming a booming and important market segment for electronic gadgets such as laptops. The student community is technologically savor and with the advent of e-learning and the proliferation of social media platforms where students 
timely share information with their peers online - their demand for electronic gadgets such i-pods and laptops have been on the increase. Thus targeting this market segment for research purposes is deemed necessary in the current study and is expected to yield practical implication to both manufacturers and retailers of electronic gadgets utilized by the student community.

Against this backdrop, the purpose of the current study is to fill this void by investigating the influence of product quality on students' purchase intention. Furthermore, this study seeks to explore the mediating role of perceived value and trust in this quality product - purchase intention relationship in the context of South Africa. Besides, the current study is expected to make academic and practical contributions to the existing marketing management literature and provide practical implications to retailers and manufacturers of electronic gadgets desired for use by students in developing countries - South Africa in particular.

The remainder of the paper is structured as follows. The next section presents a literature review section. The research methodology section which include data collection procedure, construct operationalization and measurement, follows thereafter. The subsequent section offers data analysis and results, and discussion and implications of the study findings. Lastly, in the concluding section, the limitations of the study along with suggestions for future research are highlighted.

\section{Literature Review}

\subsection{Product Quality}

In today's highly competitive marketplace buyers heavily rely upon product cues such as price, and brand image in order to deduce the quality of products they purchase (Paulins, \& Ann 2005; Oxoby \& Finnigan, 2007). The marketing literature assert that these cues are observable product or service characteristics that allow buyers to make inferences about unobservable attributes of products such as product durability or service quality, which guide buyers to determine the perceived product quality (lyengar \& Lepper, 2000; Schwartz, 2000; Roest \& Rindfleisch 2010). A study by Toivonen (2012) reveals that the quality of a tangible product can be determined by its technical characteristics and its performance aspects. However, some studies such as one by Sweeney, Soutar, and Johnson (1999) identified the ease of use and suitability of product features to the individual's needs as important contributors to product quality. In addition to that, aspects such as product flawlessness, durability, appearance and distinctiveness are among some of attributes associated with product quality (Grewal, 1997; Miyazaki et al., 2005; Roest \& Rindfleisch 2010; Bao, Bao \& Sheng 2011). In this study, product quality is defined as the consumer's judgment about a product overall excellence or superiority (Bei \& Chiao, 2001). Furthermore, perceived quality correlates with consumer purchase intention (Bao, Bao \& Sheng 2011).

\subsection{Perceived Value}

Perceived value has become a catchy concept used to explain consumer buying behavior in the marketing literature. More so, a growing body of empirical research seem to agree that business enterprises can actual achieve a competitive advantage by delivering superior value to consumers (Sweeney \& Soutar, 2001; Lin \& Wang, 2006; Chen, Shang,, \& Lin, 2008; Kuo, Deng \& Wu, 2009; Lu \& Hsiao, 2010). Thus, according to Levenburg (2005) and Sanchez-Fernandez and Iniesta-Bonillo (2009), perceived value has become a new strategic imperative for retailers and marketers alike. While there is no general consensus of what constitute customer value in the extant literature, some converging viewpoints present monetary value, quality, and expected benefits - psychological or economical as possible indicators of customer perceived value (Lin \& Wang, 2006; Kim, Chan, \& Gupta, 2007; Wang, 2008; Kuo, Deng \& Wu, 2009 Lu \& Hsiao, 2010). Some behavioral outcomes associated with customer perceived value include among others customer satisfaction, trust and purchase intention (Cronin, Brady, \& Hult, 2000; Oh, 2000; Petrick \& Backman, 2002; Sanchez-Fernandez \& IniestaBonillo, 2007; Chen, Shang, \& Lin, 2008). In the current study, perceived value is defined as the consumer's overall assessment of the utility of a product (or service) based on perceptions of what is received and what is given (Chen \& Chen, 2010).

\subsection{Trust}

Empirical evidence from the existing body of literature indicate that trust plays an important role in helping buyers to overcome perceptions of risk and uncertainty in the use and acceptance of the products they purchase (Gefen, 
Karahanna \& Straub, 2003; Pavlou \& Gefen, 2004; McKnight, 2005; Wang \& Benbasat, 2005; Jones, Lori \& Leonard 2008 ). While trust is a broad and multi-faceted concept that has been widely studied in many disciplines, the current study adopts Chinomona and Cheng, (2013) definition of trust. Trust in this study refers to "the willingness of a party to be vulnerable to the actions of another party based on the expectation that the other will perform a particular action important to the trustor, irrespective of the ability to monitor or control that other party" (Chinomona \& Cheng, 2013). Among some of the behavioral outcomes of trust identified in the retailing literature especially brand trust are brand loyalty, brand attachment, purchase intention and impulsive buying (Hong \& Cho, 2011; Chinomona, 2013).

\subsection{Purchase intention}

Purchase intention represents the possibility that consumers will plan or be willing to purchase a certain product or service in the future. An increase in purchase intention means an increase in the possibility of purchasing (Dodds, Monroe, \& Grewal, 1991; Schiffman \& Kanuk, 2007; Carrillat et al., 2009). According to Hong and Cho (2011), purchase intention is a strong proxy of making an actual purchase. The extant literature identifies among the common antecedents of buyers purchase intentions as are brand image, brand satisfaction, brand loyalty and product or brand quality (Chu \& Lu, 2007; Kim et al., 2007; Kumar, Lee, \& Kim, 2009; Lu \& Hsiao, 2010; Bian \& Forsythe, 2012; Diallo, 2012). In this current study, purchase intention is defined in the context of this study as the willingness of consumers to plan the purchase of a particular product (Carrillat et al., 2009).

\section{Conceptual Model and Hypothesis Development}

Drawing form the foregoing literature reviewed the following conceptual model has been conceptualized. Hypothesized relationships between research variables are developed thereafter. In the conceptualized model product quality is the predictor construct, student perceived product value and trust are the mediators while student purchase intention is the sole outcome construct.

Figure 1: Conceptual Model

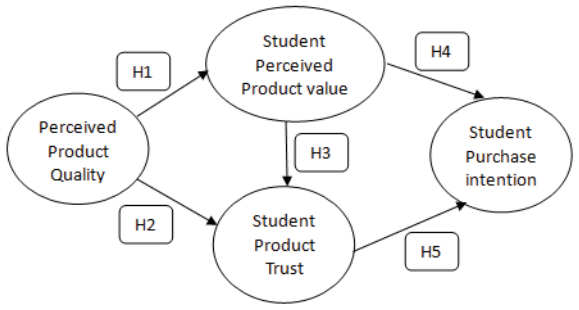

\subsection{Product Quality and Student Perceived Product Value}

There is a linkage between product quality and product value (Chen \& Chen, 2010). This is so because the quality of a product is a subjective evaluation of the degree of the overall excellence of the total product (Toivonen, 2012). In other words, the perceived product quality is a function of what the buyers perceive to be valuable attributes of the products (Woodall, 2003; Kuo, Deng \& Wu, 2009; Lu \& Hsiao, 2010). It is therefore expected that rational buyers choose the product providing the highest value with regard to the utility that the total product provides them (Toivonen, 2012). As a result of this, perceived product value has sometimes conceptualized the buyer's judgement regarding perceived product quality and market price, and the relationship between them (Sweeney \& Soutar, 2001; Woodall, 2003). Accordingly in this study, it is expected that when students perceive a product to be of good quality in terms of its attributes the students are likely to perceive it to be valuable. Thus, it is hypothesized that

H1: Perceived product quality is positively related to the students' perceived value of electronic gadgets.

\subsection{Perceived Product Quality and Student Product Trust}

According to Li, Hess, \& Valacich (2006), product quality is an important construct influencing consumers purchasing choice as well as impacting on their overall product satisfaction (Zeithaml, Valerie, Berry, Leonard, \& Parasuraman 1996; Brucks, Merrie, Zeithaml, Valerie, Naylor, Gilian , 2000). Trust involves a degree of cognitive familiarity with the product 
that the buyers want to purchase (Li, Hess, \& Valacich, 2006). In this regard, buyers will establish their cognitive familiarity based on second-hand knowledge, impressions, cognitive cues, and cognitive processes (Gefen, 2000). In the context of this study, it is expected that when students have information on an electronic gadget's quality or are satisfied with the quality of the product based on their previous experience, they are likely to trust the product (electronic gadget) they seek to purchase. Therefore, based on the empirical evidence in the extant literature it is hypothesized that:

H2: Perceived product quality is positively related to the students' trust of electronic gadgets.

\subsection{Student Perceived Product Value and Student Trust}

Studies done by Singh and Sirdeshmukh (2000) and Harris and Goode (2004), perceived value and trust have a direct positive association. Buttressing the same notion Karjaluoto, Jayawardhena, Leppaniemi, and Pihlstrom (2012) and Sirdeshmukh, Singh, and Sabol (2002) assert that when buyers perceive value in a product they are likely to trust that product. In the same vein, it is expected in the current study, that students are likely to trust electronic gadgets that they perceive to be valuable. It is therefore posited that the more the student perceive an electronic gadget to be valuable the more they can be expected to trust that electronic gadget. Hence the following hypothesis can be posited:

H3: Student perceived product value is positively related to the students' trust of electronic gadgets.

\subsection{Student Perceived Value and Purchase Intention}

Based on the exchange theory in marketing studies, it is believed that consumer's perceived value is the prerequisite of purchase intention (Wang, Yeh, \& Liao, 2013). Furthermore, as a result of a trade-off evaluation of the benefits and costs, a buyer may conclude whether a product is valuable (Kim et al., 2007). Eventually, the buyer will use this as a premise for behavioral decisions such as purchase intention (). This possible linkage has been supported in the empirical literature, for example, Chu and Lu (2007) and Lu and Hsiao (2010) found that perceived value is positively related to purchase intention in a significant way. Thus, drawing from this empirical evidence in the extent literature the current study hypothesize that:

H4: Student perceived product value is positively related to the students' purchase intention of electronic gadgets.

\subsection{Student Product Trust and Purchase Intention}

The theory of reasoned action (TRA) assert that the buyer's attitude strongly influences the behavioral intention (Fishbein \& Ajzen, 1975), and thus, attitude towards purchasing is positively associated with purchasing intention (Chong, Yang, \& Wong, 2003). It is argued in the marketing literature that trust influence the buyer's behaviour, in that buyers' trust reduces perceived risk and somewhat increases transaction intentions (Pavlou \& Gefen, 2004). In this study it is put forward that students will be expected to purchase electronic gadgets they trust. addition, trust plays a critical role in determining consumers' purchase decisions $(\mathrm{Wu}, 2013)$ in that a perception of trustfulness that a specific product or item has in the consumer's mind may provide the confidence of it sound performance and therefore motivate it purchase. Therefore, deducing from the aforementioned empirical evidence, the following hypothesis can be stated:

H5: Student perceived product value is positively related to the students' purchase intention of electronic gadgets.

\section{Research Methodology}

\subsection{Target Population, Sampling Method and Size}

Since the current study is a student perspective, the student community was used as the target population. A simple random probability sampling method was used. According to Burns and Bush (2006) with simple random sampling the probability of being selected into the sample is equal for all members of the population. A list of the Vaal University of Technology registered students was used as a sampling frame. A total of 150 usable questionnaires were the sample size for the current study.

\subsection{Measurement instruments}

Research scales were operationalized on the basis of previous work. Proper modifications were made in order to fit the 
current research context and purpose. "Trust" measure used six-item scales adapted from Suh and Han, "Perceived value" and "Intention to purchase" used a four-item scale measure adapted respectively from Lia and Hsieh; Hellier, Geursen, Carr and Rickard. Laptop quality used a five-item scale measure adopted from Lee and Chung. All the measurement items were measured on a five-point Likert-type scales that was anchored by $1=$ strongly disagree to $5=$ strongly agree to express the degree of agreement.

\subsection{Respondent Profile}

Table 1 presents the profile of the participants. The profile indicates that 81 of the participants were male which represents $54 \%$ of the total population targeted. $12 \%$ of the respondents were aged between $18-20 ; 67.3 \%$ of the participants were aged $21-25,4 \%$ were aged between $26-30$, while $22 \%$ were aged $31-35$ and finally $3.3 \%$ were aged above 36 years of age. In addition to that, $57.3 \%$ were matriculates, $7.3 \%$ were of certificate level, and $26.7 \%$ had diplomas and undergraduate degrees while $3.3 \%$ held postgraduate degrees.

Table 1: Sample Demographic Characteristics

\begin{tabular}{|c|c|c|}
\hline Gender & Frequency & Percentage \\
\hline Male & 81 & $54 \%$ \\
\hline Female & 69 & $46 \%$ \\
\hline Total & $\mathbf{1 5 0}$ & $100 \%$ \\
\hline Age & Frequency & Percentage \\
\hline $18-20$ & 18 & $12 \%$ \\
\hline $21-25$ & 101 & $67.3 \%$ \\
\hline $26-30$ & 22 & $14.7 \%$ \\
\hline $31-35$ & 4 & $2.7 \%$ \\
\hline 36 o older & 5 & $3.3 \%$ \\
\hline Total & 150 & $100 \%$ \\
\hline Academic qualification & Frequency & Percentage \\
\hline Matriculation & 86 & $57.3 \%$ \\
\hline Certificate & 11 & $7.3 \%$ \\
\hline Diploma & 40 & $26.7 \%$ \\
\hline Degree & 8 & $5.3 \%$ \\
\hline Post graduate degree & 5 & $3.3 \%$ \\
\hline Total & $\mathbf{1 5 0}$ & $100 \%$ \\
\hline
\end{tabular}

\section{Data Analysis}

Structural equation modeling (SEM) approach using Smart PLS statistical software (Ringle, Wende \& Will 2005) was used to test the research model. PLS is a component-based approach to structural equation modeling. Unlike the covariance-based approach to structural equation modeling using e.g. AMOS or LISREL statistical software, the main advantage of Smart PLS is that relatively complex, exploratory models can be developed where the main objective is predictive rather than confirmatory analysis (Chin, 1999). More so, Smart PLS is robust even with a small sample size and does not require normal distribution of the manifest variables. Since the current study sample size is relatively small (166) Smart PLS was found more appropriate and befitting when compared to AMOS and LISREL statistical software which require large data sample size. A two stage procedure to hypothesis testing using SEM recommended by Anderson and Gerbing (1988) is followed in this study. First, the study examines the measurement model by assessing the convergent and discriminant validity of items and constructs. Finally, an examination of the structural model by assessing the path coefficients between constructs is performed.

\subsection{Measurement model}

To ensure convergent validity, items should load on their respective (a priori) constructs with loadings greater than 0.6, and to ensure discriminant validity there should be no significant cross-loadings (Chin, 1998). As can be seen (Table 2), all items have loadings greater than 0.6 , with no cross-loadings greater than 0.6 , while $t$-statistics derived from 
bootstrapping (300 resamples) suggest all loadings are significant at pb0.001. As such, this confirms that all the measurement items converged well on their respective constructs.

Table 2: Accuracy Analysis Statistics

\begin{tabular}{|c|c|c|c|c|c|c|c|c|}
\hline \multicolumn{2}{|c|}{$\begin{array}{l}\text { Research } \\
\text { Construct }\end{array}$} & $\begin{array}{c}\text { LV Index } \\
\text { Value }\end{array}$ & $\begin{array}{c}\text { R-Squared } \\
\text { Value }\end{array}$ & $\begin{array}{l}\text { Cronbach's } \alpha \\
\text { value }\end{array}$ & $\begin{array}{l}\text { C.R. } \\
\text { Value }\end{array}$ & $\begin{array}{l}\text { AVE } \\
\text { Value }\end{array}$ & Communality & $\begin{array}{l}\text { Factor } \\
\text { Loading }\end{array}$ \\
\hline \multirow{4}{*}{$P Q$} & PQ1 & \multirow{4}{*}{4.273} & \multirow{4}{*}{0.000} & \multirow{4}{*}{0.6} & \multirow{4}{*}{0.803} & \multirow{4}{*}{0.5} & \multirow{4}{*}{0.5} & 0.856 \\
\hline & PQ 2 & & & & & & & 0.655 \\
\hline & $\mathrm{PQ} 3$ & & & & & & & 0.727 \\
\hline & PQ 4 & & & & & & & 0.587 \\
\hline \multirow{4}{*}{ PV } & PV1 & \multirow{4}{*}{4.349} & \multirow{4}{*}{0.225} & \multirow{4}{*}{0.8} & \multirow{4}{*}{0.896} & \multirow{4}{*}{0.6} & \multirow{4}{*}{0.6} & 0.796 \\
\hline & PV 2 & & & & & & & 0.665 \\
\hline & PV3 & & & & & & & 0.863 \\
\hline & PV 4 & & & & & & & 0.808 \\
\hline \multirow{6}{*}{ TR } & TR1 & \multirow{6}{*}{4.328} & \multirow{6}{*}{0.505} & \multirow{6}{*}{0.8} & \multirow{6}{*}{0.901} & \multirow{6}{*}{0.6} & \multirow{6}{*}{0.6} & 0.796 \\
\hline & TR2 & & & & & & & 0.766 \\
\hline & TR3 & & & & & & & 0.861 \\
\hline & TR4 & & & & & & & 0.852 \\
\hline & TR5 & & & & & & & 0.714 \\
\hline & TR6 & & & & & & & 0.659 \\
\hline \multirow{4}{*}{$\mathrm{PI}$} & PI 1 & \multirow{4}{*}{4.589} & \multirow{4}{*}{0.356} & \multirow{4}{*}{0.8} & \multirow{4}{*}{0.905} & \multirow{4}{*}{0.7} & \multirow{4}{*}{0.7} & 0.862 \\
\hline & $\mathrm{PI} 2$ & & & & & & & 0.812 \\
\hline & $\mathrm{PI} 3$ & & & & & & & 0.831 \\
\hline & $\mathrm{PI} 4$ & & & & & & & 0.850 \\
\hline
\end{tabular}

Note: PQ=Product Quality; PV=Perceived Value; TR=Trust; PI=Purchase Intention

C.R.: Composite Reliability; AVE: Average Variance Reliability

* Scores: 1 - Strongly Disagree; 3 - Neutral; 5 - Strongly Agree

Constructs should have an average variance extracted (AVE) of more than 0.5 and a composite reliability of more than 0.7 (convergent validity), and inter-construct correlations should be less than the square-root of the AVE (discriminant validity) (Chin, 1998). As can be seen (Table 2), all constructs exceed these criteria, with AVE and CR generally slightly equal or greater than 0.6 and 0.9 , respectively, and the square-root of the AVE being at least 0.77 greater than the interconstruct correlations (Table 3). All in all, these results confirm the existence of discriminant validity of the measurement used in this study.

Table 3: Correlations between Constructs

\begin{tabular}{|l|l|l|l|l|}
\hline \hline Research Constructs & PQ & PV & TR & PI \\
\hline Product Quality (PQ) & 1.000 & & & \\
\hline Perceived Value (PV) & 0.473 & 1.000 & & \\
\hline Trust (TR) & 0.684 & 0.493 & 1.000 & \\
\hline Purchase Intention (PI) & 0.554 & 0.602 & 0.413 & 1.000 \\
\hline \hline
\end{tabular}

\subsection{Structural model}

The results of the PLS analysis is shown in Figure 2 and Table 4. Standardized path coefficients are expected to be at least 0.2 , and preferably greater than 0.3 (Chin, 1998). The reliability of each coefficient is assessed from bootstrapping (300 resamples). Support is provided for all the five hypotheses $(\mathrm{H} 1, \mathrm{H} 2, \mathrm{H} 3, \mathrm{H} 4$ and $\mathrm{H} 5)$. All other path coefficients are above 0.2 and significant (pb0.001). As indicated in Figure 2 and Table 4, the path coefficients are $0.474,0.582,0.217$, 0.170 and 0.494 for $\mathrm{H} 1, \mathrm{H} 2, \mathrm{H} 3, \mathrm{H} 4$ and $\mathrm{H} 5$ respectively. 
Figure 2: Measurement and Structural Model Results

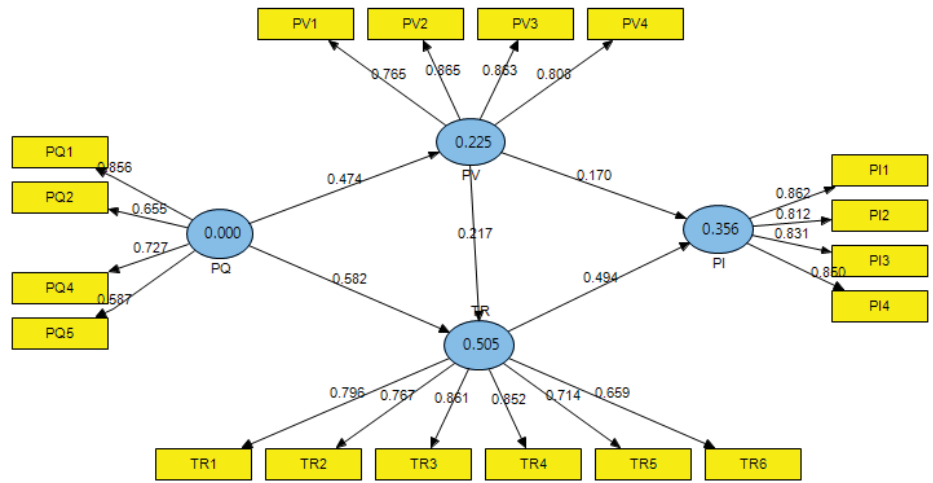

Note: PQ=Product Quality; PV=Perceived Value; TR=Trust; PI=Purchase Intention

Table 4 provides the T-statistics for the hypothesised relationships. The minimum T-statistics is 4.445 and therefore exceeds the recommended threshold of 2 . This further confirms that all the hypothesised relationships are statistically significant and hence are supported.

Table 4: Results of Structural Equation Model Analysis

\begin{tabular}{|l|c|c|c|c|}
\hline \hline \multicolumn{1}{|c|}{ Proposed Hypothesis Relationship } & Hypothesis & Path Coefficients & T-Statistics & Rejected / Supported \\
\hline Product Quality (PQ) $\rightarrow$ Perceived Value (PV) & H1 & 0.474 & 6.263 & Supported \\
Product Quality (PQ) $\rightarrow$ Trust (TR) & H2 & 0.582 & 9.498 & Supported \\
Perceived Value (PV) $\rightarrow$ Trust (TR) & H3 & 0.217 & 2.810 & Supported \\
Perceived Value (PV) $\rightarrow$ Purchase Intention (PI) & H4 & 0.170 & 1.805 & Not Supported \\
Trust (TR) $\rightarrow$ Purchase Intention (PI) & H5 & 0.494 & 5.268 & Supported \\
\hline \hline
\end{tabular}

Note: PQ=Product Quality; PV=Perceived Value; TR=Trust; PI=Purchase Intention

Overall, $\mathrm{R}^{2}$ for student perceived product value, student product trust and purchase intention in Figure 2, indicate that the research model explains $22.5 \%, 50.5 \%$ and $35.6 \%$ respectively of the variance in the endogenous variables. Following formulae provided by Tenenhaus, Vinzi, Chatelin \& Lauro, (2005), the global goodness-of-fit (GoF) statistic for the research model was calculated using the equation:

$$
\mathrm{GoF}=\sqrt{\overline{\mathrm{AVE}^{*}} \mathrm{R}^{2}-}
$$

Where AVE represent the average of all AVE values for the research variables while $\mathrm{R}^{2}$ represents the average of all $R^{2}$ values in the full path model

The calculated global goodness of fit (GoF) is 0.41 , which exceed the threshold of $\mathrm{GoF}>0.36$ suggested by Wetzels, Odekerken-Schröder \& van Oppen (2009). Thus, this study concludes that the research model has a good overall fit.

\section{Discussion and Conclusion}

The purpose of the current research was to examine the influence of quality product, perceived value, and trust on students' intention to purchase electronic gadgets. In particular, five hypotheses were posited. To test the hypothesis data were collected from the Vaal University of Technology registered students in the Gauteng province in South Africa. The empirical results supported all the postulated research hypotheses in a significant way except $\mathrm{H} 4$ which although found a positive relationship between student perceived product value and purchase, the relationship was insignificant. Important to note about the study findings is the fact that the product quality has a stronger effects on student product trust (0.582) than on perceived product value (0.474). Perceived product value influences on trust $(0.217)$ in a significant way but has an insignificant influence on purchase intention (0.170). However, trust has also a significant influence on purchase intention (0.494). 


\subsection{Implications of the study}

The current research is one of the first to study these relationships using data collected from students at the Vaal University of Technology in South Africa. Because of the growing importance in terms of the size of the students' population, it represents a very attractive and highly profitable market for businesses operating in the electronic gadgets industry, hence these findings provide fruitful implications for both businessmen and other practitioners and academicians.

On the academic side, this study makes a significant contribution by adding new literature to the existing marketing and retailing literature from a student perspective. On the practitioners' side, the findings bear practical implications. Manufacturers and retailers of electronic gadgets such laptops needed by students should adopt strategies that enhance the quality of their products since this has a significant influence on the student's products' trust and their purchase intention.

\subsection{Limitations and Future Research}

Although this study makes significant contributions to both academia and practice, it was limited in some ways, and therefore some future research directions are suggested. First, the data were gathered from the students registered at the Vaal University of technology confined within the Gauteng province. Perhaps, the results would be more informative if data from students in other major cities of the country are included. Future studies may be conducted by using data from other tertiary institutions across the country. Second, the current study was limited to university students. Subsequent research should contemplate replicating this study in other developing countries for results comparisons. Future studies can also extend the current study conceptual framework by studying the effects of a larger set of variables. For instance, the influence of brand image and brand preference associated with the identified variables as constructs explaining purchase intention could be investigated.

\section{References}

Ailawadi, K.L., Keller, K.L. 2004. Understanding retail branding: Conceptual insights and research priorities. Journal of Retailing, 80 (4): 331-342.

Bao, Y., Bao, Y And Sheng, S. 2011. Motivating Purchase of Private Brands: Effects of Store Image, Product Signatureness, and Quality Variation. Journal of Business Research, 64: 220-226.

Bei, L.T., \& Chioa, Y.C. 2001. An integrated model for the effect of perceived product, perceived service quality, and perceived price fairness on consumer satisfaction and loyalty. Journal of consumer satisfaction and dissatisfaction and complaining behaviour, (14): 126-140.

Berry, L.L. 1995. Relationship marketing of services: Growing interest, emerging perspectives.Journal of the Academic of Marketing Science, 23: 236-245.

Bian, Q., \& Forsythe, S. 2012. Purchase intention for luxury brands: A cross cultural comparison. Journal of Business Research, 65: 1443-1451.

Brucks, Merrie, Zeithaml, Valerie A., Naylor, Gilian. 2000. Price and brand name as indicators of quality dimensions for consumer durables. Journal of the Academy of Marketing Science, 28 (3): 359-374.

Burns, A.C. \& Bush, R.F. 2006. Marketing Research. New Jersey: Pearson Prentice Hall.

Carrillat, F.A., Jaramillo, F., Mulki, J.P. 2009. Examining the impact of service quality: A meta-analysis of empirical evidence. Journal of Marketing Theory and Practice, 17 (2): 95-110.

Chen, C.F. \& Chen, F.S. 2010. Experience quality, perceived value, satisfaction and behavioral intentions for heritage tourists. Tourism Management, 31: 29-35.

Chen, C.F. 2008. Investigating structural relationships between service quality, perceived value, satisfaction, and behavioral intentions for air passengers: evidence from Taiwan. Transportation Research Part A, 42(4): 709-717.

Chen, Y.C, Shang, R.A., \& Lin, A.K. 2008. The intention to download music files in a P2P environment: Consumption value, fashion, and ethical decision perspectives. Electronic Commerce Research and Applications, 7(4): 411-422.

Chinomona, R \& Cheng, J (2013), "Distribution Channel Relational Cohesion Exchange Model: A Small-to-Medium Enterprise Manufacturer's Perspective," Journal of Small Business Management, 51(2), 256-275

Chinomona, R,. \& Sandada, M. 2013. Service Quality Level as the Determinant of Consumer Emotional Loyalty and Fantasy in South Africa's Pick \& Pay Chain Stores. Mediterranean Journal of Social Sciences, 4 (3): 579586

Chong, B., Yang, Z., \& Wong, M. 2003. Asymmetrical impact of trustworthiness attributes on trust, perceived value and purchase intention: A conceptual framework for cross-cultural study on consumer perception of online auction. In Proceedings of the 5th international conference on electronic commerce Pittsburgh, Pennsylvania.

Chu, C.W., \& Lu, H.P. 2007. Factors influencing online music purchase intention in Taiwan: An empirical study based on the value- 
intention framework. Internet Research, 17(2): 139-155.

Chu, C.W., \& Lu, H.P. 2007. Factors influencing online music purchase intention in Taiwan: An empirical study based on the valueintention framework. Internet Research, 17(2): 139-155.

Chu, C.W., \& Lu, H.P. 2007. Factors influencing online music purchase intention in Taiwan: An empirical study based on the valueintention framework. Internet Research, 17(2): 139-155.

Churchill, G. A. 2011. Basic marketing research. $4^{\text {th }}$ ed. Ohio: Thomson Learning.

Corritore, C. L., Kracher, B., \& Wiedenbeck, S. 2003. Online trust: Concepts, evolving themes, a model. International Journal of HumanComputer Studies, 58: 737-758.

Cronin, J. J., Brady, M. K., \& Hult, G. T. M. 2000. Assessing the effects of quality, value, and customer satisfaction on consumer behavioral intentions in service environments. Journal of Retailing, 76(2): 193-218.

Cronin, J. J., Brady, M. K., \& Hult, G. T. M. 2000. Assessing the effects of quality, value, and customer satisfaction on consumer behavioral intentions in service environments. Journal of Retailing, 76(2): 193-218.

Crosby, L.A., Evans, K.R., \& Cowles, D. 1990. Relationship quality in services selling: An interpersonal influence perspective. Journal of Marketing, 54: 68-81.

Diallo, M.F. 2012. Effects of store image and store brand price-image on store brand purchase intention: Application to an emerging market. Journal of Retailing and Consumer Services, 19: 360-367.

Dodds, W.B., Monroe, K.B., Grewal, D. 1991. Effects of price, brand, and store information on buyers' product evaluation. Journal of Marketing Research, 28 (3): 307-319.

Fishbein, M., Ajzen, I., 1975. Belief, attitude, intention, and behavior: An introduction to theory and research. Addison-Wesley Publishing Company, MA.

Gale, B.T., 1994. Managing Customer Value. Creating Quality and Service That Customers Can See. Free Press, New York.

Gefen, D., Karahanna, E., Straub, D.W. 2003. Trust and TAM in online shopping: an integrated model. MIS Quarterly, 27 (1): 51-90.

Gefen, D.2000. E-commerce: the role of familiarity and trust. Omega, 28 (6): 725-737.

Grewal, D. 1997. Development of a Multidimensional Measure of Perceived Product Quality. Journal of Quality Management, 2 (1): 88 111.

Harris, L.C., \& Goode, M.M.H. 2004. The four levels of loyalty and the pivotal role of trust: A study of online service dynamics. Journal of Retailing, 80(2): 139-158.

Hong, I.B., \& Cho, H. 2011. The impact of consumer trust on attitudinal loyalty and purchase intentions in B2C e-marketplaces: Intermediary trust vs. seller trust. International Journal of Information Management, 31: 469- 479.

lyengar, S. S., Lepper, M. R. 2000. When choice is demotivating: can one have too much of a good thing? .Journal of Personality and Social Psychology, 79 (6): 995-1006.

Jones, K., Lori N., \& K. Leonard. 2008. Trust in consumer-to-consumer electronic commerce. Information \& Management, 45: 88-95.

Karjaluoto, H., Jayawardhena, C., Leppaniemi, M., \& Pihlstrom, M. 2012. How value and trust influence loyalty in wireless telecommunications industry. Telecommunications Policy, 36: 636-649.

Kim, H.W., Chan, H. C., \& Gupta, S. 2007. Value-based adoption of Mobile Internet: An empirical investigation. Decision Support Systems, 43(1): 111-126.

Kim, H.W., Chan, H. C., \& Gupta, S. 2007. Value-based adoption of Mobile Internet: An empirical investigation. Decision Support Systems, 43(1): 111-126.

Kotler, P., Keller, K.L. 2005. Marketing Management, Twelfth Edition. Pearson Education Inc.

Kumar, A., Lee, H.J., \& Kim, Y.K. 2009. Indian consumers' purchase intention toward a United States versus local brand. Journal of Business Research, 62: 521-527.

Kuo, Y.F., Wub, C.M., \& Deng, W.J. 2009. The relationships among service quality, perceived value, customer satisfaction, and postpurchase intention in mobile value-added services. Computers in Human Behavior, 25: 887-896.

Levenburg, N.M. 2005. Delivering customer value online: an analysis of practices, applications, and performance. Journal of Retailing and Consumer Services, 12 (5): 319-331.

Li, X., Hess, T.J., \& Valacich, J.S. 2006. Using attitude and social influence to develop an extended trust model for information systems. Database for Advances in Information Systems, 37 (2-3): 108-124.

Lin, H.H., \& Wang, Y.S. 2006. An examination of the determinants of customer loyalty in mobile commerce contexts. Information \& Management, 43(3): 271-282.

Lu, H.P., \& Hsiao, K.L. 2010. The influence of extro/introversion on the intention to pay for social networking sites. Information \& Management, 47(3): 150-157.

Luo, X., Li, H., Zhang, J., \& Shim, J. P. 2010. Examining multi-dimensional trust and multifaceted risk in initial acceptance of emerging technologies: an empirical study of mobile banking services. Decision Support Systems, 49(2): 222-234.

Malhortra, N.K. \& Birks, D.F. 2003. Marketing research: An applied approach. $2^{\text {nd }}$ ed. London: Prentice-Hall.

Mayer, R.C., Davis, J.H., Schoorman, F.D. 1995. An integrative model of organizational trust. The Academy of Management Review, 20 (3): 709-734.

Mcknight, D. H., \& Chervany, N. L. 2002. What trust means in e-commerce customer relationships: an interdisciplinary conceptual typology. International Journal of Electronic Commerce, 6(2): 35-59.

Mcknight, D.H. 2005. Trust in information technology. In: Davis, G.B. (Ed.). The Blackwell Encyclopedia of Management. Blackwell, Maiden, MA, pp. 329-331. 
Mcknight, D.H., Cummings, L.L., Chervany, N.L. 1998. Initial trust formation in new organizational relationships. The Academy of Management Review, 23 (3): 473-490.

Miyazaki, Anthony D., Grewal, Dhruv, Goodstein, Ronald, C. 2005. The effect of multiple extrinsic cues on quality perceptions: a matter of consistency. Journal of Consumer Research, 146-153.

Oh, H. 2000. Diner's perceptions of quality, value and satisfaction. Cornell Hotel and Restaurant Administration Quality, 41(3): 58-66.

Oxoby, Robert J., Finnigan, Hugh. 2007. Developing heuristic-based quality judgments: blocking in consumer choice. Psychology \& Marketing, 24: 295-313.

Paul, C., Wua, S., Yeh, G. Y., \& Hsiao, C.R. 2011. The effect of store image and service quality on brand image and purchase intention for private label brands. Australasian Marketing Journal, 19: 30-39.

Paulins, V. \& Ann. 2005. An analysis of customer service quality to college students as influenced by customer appearance through dress during the in-store shopping process. Journal of Retailing and Consumer Services, 12: 345-355.

Pavlou, P. A., \& Gefen, D. 2004. Building effective online marketplaces with institution-based trust. Information Systems Research, 15(1): 37-59.

Pavlou, P.A., Gefen, D. 2004. Building effective online marketplaces with institution-based trust. Information Systems Research, 15 (1): 37-59.

Petrick, J. F., \& Backman. 2002. An examination of the construct of perceived value for the prediction of golf travelers' intentions to revisit. Journal of Travel Research, 41(1): 38-45.

Roest, H., \& Rindfleisch, A. 2010. The influence of quality cues and typicality cues on restaurant purchase intention. Journal of Retailing and Consumer Services, 17: 10-18.

Sanchez-Fernandez, R., \& Iniesta-Bonillo, A.M. 2009. Efficiency and quality as economic dimensions of perceived value: Conceptualization, measurement, and effect on satisfaction. Journal of Retailing and Consumer Services, 16: 425-433.

Schiffman, L.G., Kanuk, L.L. 2007. Consumer Behavior, ninth ed. Prentice-Hall Inc, NJ.

Sheth, J. N., Newman, B. I., \& Gross, B. I. 1991. Consumption values and market choice. Cincinnati, OH: South Western Publishing Company.

Singh, J., \& Sirdeshmukh, D. 2000. Agency and trust mechanisms in consumer satisfaction and loyalty judgments. Journal of the Academy of Marketing Science, 28(1): 150-168.

Sirdeshmukh, D., Singh, J., \& Sabol, B .2002. Consumer trust, value, and loyalty in relational exchanges. Journal of Marketing, 66: 1537.

Steenkamp, J-B.E.M., 1990. Conceptual model of the quality perception process. Journal of Business Research, 309-333.

Sweeney, J. C., \& Soutar, G. N. 2001. Consumer perceived value: The development of a multiple item scale. Journal of Retailing, 77(2): 203-220.

Sweeney, J. C., \& Soutar, G. N. 2001. Consumer perceived value: The development of a multiple item scale. Journal of Retailing, 77(2): 203-220.

Toivonen, R.M. 2012. Product quality and value from consumer perspective: An application to wooden products. Journal of Forest Economics, 18: 157-173.

Tsweeney, J., Soutar, G., \& Johnson, L. 1999. The Role of Perceived Risk in the Quality-Value Relationship: A Study in a Retail Environment. Journal of Retailing, 75: 77-105.

Verhoef, P.C., Francis, P.H., \& Hoekstra, J.C. 2002. The effect of relational constructs on customer referrals and number of services purchased from multiservice provider: Does age of relationship matter. Journal of the Academy of Marketing Science, 30(3): 202-216.

Wang, W., Benbasat, I. 2005. Trust in and adoption of online recommendation agents. Journal of the Association for Information Systems, 6 (3): 72-101.

Wang, Y.S, Hsuan Yeh, C.H., \& Liao, Y.W. 2013. What drives purchase intention in the context of online content services? The moderating role of ethical self-efficacy for online piracy. International Journal of Information Management, 33: $199-208$.

Wang, Y.S. 2008. Assessing e-commerce systems success: A respecification and validation of the DeLone and McLean model of IS success. Information Systems Journal, 18(5): 529-557.

Wang, Y.S., Yeh, C.H., \& Liao, Y.W. 2013. What drives purchase intention in the context of online content services? The moderating role of ethical self-efficacy for online piracy. International Journal of Information Management, 33:199- 208.

Wegner, T. 2000. Quantitative Methods. Cape Town: Juta.

Wiedenfels, G. 2009. Trust of potential buyers in new entrepreneurial ventures. Gabler, Wiesbaden: GWV Faceverlage GmbH.

Wu, I.L. 2013. The antecedents of customer satisfaction and its link to complaint intentions in online shopping: An integration of justice, technology, and trust. International Journal of Information Management, 33: 166- 176.

Zeithaml, V. A. 1988. Consumer perceptions of price, quality, and value: A means end model and synthesis of evidence. Journal of Marketing, 52(3): 2-22.

Zeithaml, Valerie A., Berry, Leonard, L., Parasuraman, A. 1996. The behavioral consequences of service quality. Journal of Marketing, 60: $31-46$. 